\title{
Movement and Transformation
}

\author{
JENANNE FERGUSON
}

This is my first full issue as the new editor of Sibirica, and I want to provide a brief overview of my previous involvement with the journal. I am a linguistic and sociocultural anthropologist who works primarily in the Sakha Republic (Yakutia) on issues related to language maintenance, language practices, urbanization, and verbal art. I have been working with Sibirica in some capacity for the past ten years, beginning as a graduate student assistant to editors Alexander King and then John Ziker. I then joined the group of associate editors in 2014 after I completed my PhD. I will strive to continue the legacies of my predecessors who have grown this journal to what it is today by supporting and developing its strong, multidisciplinary focus.

Although this is not a special issue, each of the ethnographically informed articles published here complements the others; all of these submissions involve movement and transformation-literal, ideological, or metaphorical. The issue opens with Kirill Istomin's investigation of rivers as an organizational schema for the mobility of Khanty, Komi, and Nenets communities in northwestern Russia. The author deftly contrasts the tensions between the river-centric system and those of the roads and railroads in terms of navigation and regional sociopolitical forces. Istomin examines what these shifts in movement infrastructure mean for the long-held livelihoods of the region's indigenous inhabitants as their access to economic and political power. He also entwines trajectories through space with life trajectories. The next article takes us to Buriatiia, where the author also examines the power of the road. Focusing on the Mondy-Orlik road and life in the Okinskii district, Anna Varfolomeeva reveals how connectivity and infrastructure lead to economic opportunity and the potential loss of a sense of place for the region. Her focus on local relationships with the land and people's "social" relationships with the road in question is elucidated in this exploration of how new possibilities for mobility translate relations between humans as well as nonhuman actors. Both Varfolomeeva and Istomin highlight how the effects of physical and metaphorical transformations to movement have both overt and subtle 
social impacts on the lives of people who travel through their respective places and spaces.

Varfolomeeva's focus on engagement with the land is echoed by Donatas Brandišauskas, who provides an analysis of historical and contemporary interactions with rock art in Eastern Siberia and the Far East. Brandišauskas demonstrates how archaeologists and other researchers, as well as indigenous Evenki, engage with these artworks while moving across the land. He also touches on how their practices for encountering and interacting with the sites on physical and spiritual levels have mutually influenced each other, with a particularly strong ontological transformation occurring for the nonindigenous researchers. The author focuses on the central role of Evenki herders and hunters in opening up these spaces for researchers and highlights the agency of indigenous people in shaping how this research unfolded. Brandišauskas also stresses how the knowledge-creating processes of both parties were dynamic, remaining unfinished and always in motion through the experiences these groups had in pursuit of these sites.

Finally, Svetlana Huusko's article engages with the themes of movement more metaphorically through her discursive analysis of a community museum's depiction of the Evenki culture in Buriatiia. However, we can follow a thread from Brandišauskas's article in that Huusko also sheds light on the way ideological frameworks between locals, incomers, and researchers-who hold a more powerful position in producing and legitimizing knowledge-differ and clash. Here, however, there is much less give-and-take between the indigenous community and the nonindigenous researchers or knowledge creators. Huusko shows how the museum in Nizhneangarsk relies heavily on institutional, top-down narratives to position Evenkis in local life and shape how young Evenkis may come to see themselves, rather than allowing more fluid local understandings to emerge in the museum space. Similar to Istomin's examination of how the infrastructural focus on the (rail)road changes not only mobility patterns but also metaphorical understandings of movement and place, Huusko provides a case of how state-approved framings of indigenous lifeways overlay a figurative infrastructure over Evenki culture, erasing the dynamism of Evenki people's everyday lived practices. 